\title{
Grain Chemical Composition as Affected by Genetic Back- grounds and Toxigenic Aspergillus favus Inoculation in Corn Hybrids
}

\author{
Nacer Bellaloui ${ }^{*}$, Hamed K. Abbas ${ }^{2}, \mathrm{H}$. Arnold Bruns ${ }^{3}$, and Alemu Mengistu ${ }^{4}$ \\ ${ }^{1}$ Crop Genetic Research Unit, USDA-ARS, Stoneville, USA; ${ }^{2}$ Biological Control of Pests Research Unit, USDA- \\ ARS, Stoneville, USA; ${ }^{3}$ Crop Production Systems Research Unit, USDA-ARS, Stoneville, USA; ${ }^{4}$ Crop Genetics \\ Research Unit, USDA-ARS, Jackson, TN, USA.
}

Received: September 8, 2016 / Accepted: October 6, 2016

\begin{abstract}
Mycotoxins are toxic secondary metabolites commonly found in corn and known to cause health issues to human and animals. Information on the relationship between corn grain inoculated with mycotoxins and grain nutrients (protein, oil, fatty acids, sugars, and amino acids) in corn hybrids, especially stacked-gene hybrids is very limited. The objective of this study was to investigate the nutritional advantage of stacked-gene hybrids (Stgene) over non-genetically modified organisms (non-GMO) corn or glyphosate-resistant corn (RR). The experiment was conducted in two locations (clay and sandy soils) in 2011, irrigated, and inoculated with toxigenic Aspergillus flavus using four hybrids of stackedgene, four of RR, and two non-GMO (conventional). Non-inoculated plots were used as control. The results showed that stacked-gene hybrids had no observable nutritional advantage over RR or non-GMO as all hybrid classes accumulated adequate nutrients in their grains; this effect could be due to adequate concentrations of nutrients in the soil. Higher levels of grain protein, carbohydrates (glucose, reducing sugars, and starch), oleic acid, total amino acids, and some minerals were observed under inoculated conditions in clay and sandy soils indicated a possible osmotic adjustment role of these compounds as stress indicators and osmoprotectants under inoculated conditions. Grain nutrients in clay soil were higher than those in sandy soils; nutrient differences could be due to sandy soil possibly suffering drier conditions, especially inoculated soil, reducing nutrient uptake and nutrients mobility to the grain. This study provides advanced knowledge on the
\end{abstract}

relationship between grain nutrients and mycotoxins in corn hybrids. It is also useful to the corn breeders to understand the responses of grain nutrients to fungal diseases in corn hybrids.

Keywords: Grain Nutrition, Grain Chemical Composition, Stacked-Gene Corn, Hybrids, Mycotoxins, Aflatoxin, Fumonisin.

\section{Introduction}

Aflatoxins are toxic secondary metabolites commonly found in corn produced by Aspergillus spp., predominantly Aspergillus flavus. The amount of aflatoxins in crops is regulated by the government of each country; the United States has set the maximum aflatoxin level for direct human consumption at $20 \mathrm{ppb}$. Aflatoxin is known to cause liver cancer in humans as well as acute toxicity and death in poultry (Abbas, 2005; CAST, 2003). Cyclopiazonic acid (CPA) is also a mycotoxin produced by Aspergillus and Penicillium spp., including A. flavus fungi growing on feedstuff, and it is often found along with aflatoxins in animal feeds. CPA is also produced by Penicillium cyclopium (Abbas et al., 2011; King et al., 2011; Miller et al., 2011). CPA causes a disturbance of calcium metabolism in muscles, often causing death in animals. Fusarium spp. are vectors for mycotoxin contamination, including zearalenone, which causes vulvaginitis (hyperestrogenism) in swine, and deoxynivalenol (DON), which causes feed refusal, nausea, and vomiting (CAST, 2003). Fumonisins are mycotoxins

* Corresponding author: nacer.bellaloui@ars.usda.gov 
produced by Fusarium spp. such as Fusarium verticillioides and Fusarium proliferatum, and are known to cause leukoencephalomalacia in horses and pulmonary edema in pig. The allowable level of fumonisins in maize and maize products has been set by FDA at 2-4 ppm (CAST, 2003; NTP, 1999).

Corn grown under heat and drought stress is susceptible to infection by $A$. flavus and Fusarium spp., resulting in kernels contaminated with aflatoxins and fumonisins. Insect infestation promotes fungal inoculation and mycotoxin contamination through insects-burrowing through the husks or down the silk channels, opening infection routes for air- or dust-borne fungal pathogens, causing further contamination and kernel damage. It has been reported that insects managed by Bt toxins can act as vectors of fungal pathogens (Abbas et al., 2009), and if this vector is controlled, Bt corn is thought to be less susceptible to mycotoxinproducing plant pathogens. It is well known that European corn borer (O. nubilalis) is one of most economically important insect pests in corn producing areas of the United States. In the southern United States, larvae enter diapause, overwinter primarily in the stalks, and in spring adults emerge as moths, travel before mating and laying eggs on the upper surface of maize leaves, feeding on corn ear (Cook et al., 2016). It has been reported that in spite of that, not all types of $\mathrm{Bt}$ toxins would give the same level of protection (NTP, 2001), and transgenic corn may be protected against European corn borer (Abbas et al., 2016). The possible effects of transgenic corn hybrids on mycotoxin control and the advantage of transgenic corn hybrids, including stacked gene hybrids, was studied, and its influence on reduced mycotoxin contamination, resulted from insect infection, was also evaluated (Abbas et al., 2016). They used what is called "stacked-gene" hybrids (hybrids released with multiple insect resistance genes and herbicide resistance genes). They compared ten commercially available corn hybrids: two nontransgenic, four stacked-gene transgenic, and four transgenic with glyphosate tolerance only to determine if any hybrid class had the advantage of reduced mycotoxin contamination. They found that mycotoxin production was affected by soil type, with lower levels of mycotoxins in the hybrids planted in clay soil vs. sandy soil. Also, they found that there were no significant differences in mycotoxin production amongst the hybrid classes. They concluded that further research is needed to identify conditions where transgenic hybrids might produce higher yields and lower mycotoxin levels. Contaminated corn with mycotoxins, including aflatoxins and fumonisins leads to major food safety issues, production losses, and grain waste (Robens and Cardwell, 2003). Aflatoxins and fumonisins can be a major problem in the southern U.S., although fumonisins are spread more northerly areas of the U.S. (Abbas, 2005; Abbas et al., 2015; CAST, 2003). Mycotoxin production is affected by environmental conditions such as heat, drought, insect infestation and various plant diseases (Diener et al., 1987; Payne, 1992; Abbas et al., 2002; Bruns and Abbas, 2005; De la Campa et al., 2005; Bruns and Abbas, 2006; Abbas et al., 2007). It was reported that stacked-gene hybrids can reduce mycotoxins, as they are formulated to affect mycotoxin production.

Effects of transgenics on aflatoxin contamination in corn have been studied, but no conclusion or recommendations have been made. For example, Williams et al. (2010) and Wiatrak et al. (2005) reported lower levels of aflatoxin in Bt lines and hybrids, respectively. Other studies found no significant effects of Bt hybrids on aflatoxin or inconsistent effects of Bt hybrids on fumonisins. While studying the western bean cutworm and European corn borer infestation, it was found that there was no significant effect of $\mathrm{Bt}$ on aflatoxin and variable effect of $\mathrm{Bt}$ on fumonisin content (Catangui and Berg, 2006). Abbas et al. (2009) studied the effect of 65 hybrids on the aflatoxin level over three years, but the effect of transgene on aflatoxin levels could not be demonstrated. Abbas et al (2013) reported that Bt corn lacks protection against aflatoxin contamination or no protection against the insects (e.g., corn earworm or fall armyworm) that limit the spreading of Aspergillus infection. Bt corn hybrids showed clearer effects on reducing fusarium mycotoxins. For example, the first-generation $\mathrm{B} t$ corn hybrids demonstrated a resistance to fusarium ear rot along with lower levels of fumonisin contamination in harvested kernels (Munkvold et al., 1999). Meta-analysis concluded that $\mathrm{B} t$ corn showed lower level in one or more fusarium mycotoxins in 19 of 23 studies (Ostry et al., 2010).

Relationship between corn grain mycotoxins and grain nutrients (protein, oil, fatty acids, sugars, and amino acids) has been studied in glyphosate-resistant hybrids. For example, Viquez et al. (1994) evaluated the correlation between aflatoxin produced by Aspergillus flaws and nutrients $\left(\mathrm{Mg}^{2+}, \mathrm{Zn}^{2+}\right.$, and $\left.\mathrm{Ca}^{2+}\right)$ and the polynomial and sugars (xylose, fructose, glucose, and mannose) content in corn grain. They found that the levels of aflatoxin were highly correlated $(\mathrm{P} \leq 0.01)$ with minerals $\left(\mathrm{Mg}^{2+}\right.$, $\mathrm{Zn}^{2+}$, and $\mathrm{Ca}^{2+}$ ) and their polynomial effect. No effects of $\mathrm{xy}$ lose, fructose, and glucose/mannose content in corn grain on aflatoxin level were seen, but a multicollinearity relationship between glucose/mannose and aflatoxin level was observed. They concluded that aflatoxin production by A. flaws was correlated with zinc, magnesium, and calcium, and temperature, and environmental factor, and played a stimulatory role for aflatoxin production by A. flavus (Viquez et al., 1994).

Aflatoxin production is influenced by catabolic activity, reduced coenzyme level, energy charge, and metal ions (Dutton, 1988; Llewellyn et al., 1988). Other studies identified that biological, chemical, and environmental factors are associated with the biosynthesis of aflatoxin production and had a direct relationship with them (Ellis et al., 1991), and among these chemical factors were high level of carbohydrates and a low level of proteins (Thalmann, 1990; Ellis et al., 1991). Carbohydrates supply the two carbon precursors for toxin synthesis, and in this regard, corn is considered a good substrate for aflatoxin production because it has high a level of carbohydrates (approximately $63 \%$ ) and low nitrogen (10\%) content (Wiseman and Buchanan (1987). Also, the biosynthesis of aflatoxin is influenced by some metal ions such as cadmium $\left(\mathrm{Cd}^{2+}\right)$, magnesium $\left(\mathrm{Mg}^{2+}\right)$, calcium $\left(\mathrm{Ca}^{2+}\right)$, and zinc $\left(\mathrm{Zn}^{2+}\right)$ (Failla et al., 1986; Stossel, 1986; Ellis et al., 1991 ; Viquez et al., 1994). Specific attention was given to $\mathrm{Zn}$ and $\mathrm{Ca}$ as $\mathrm{Zn}$ is required for aflatoxin biosynthesis (Failla et al., 1986; Stossel, 1986), and Ca2+ content may reduce aflatoxin contamination (Mixon et al., 1984). Other researchers Abdollahi and Buchnan (1981a) investigated the ability of compounds in- 
ducing aflatoxin biosynthesis by Aspergillus parasiticus by transferring the cultured organism from peptone basal medium that does not support aflatoxin production to a medium containing a test compound. They found that ribose, xylose, glucose, fructose, sorbose, mannose, galactose, maltose, sucrose, raffinose, and glycerol induced aflatoxin production. Also, they found that aflatoxin biosynthesis was not induced by lactose, lactic acid, sodium pyruvate, oleic acid, citric acid, sodium acetate, $\alpha$-methylD-glucoside, 3-0-methyl-D-glucoside, cAMP, or cGMP. They concluded that the induction of aflatoxin was due to the specific available metabolizable carbon sources that regulate aflatoxin formation. It was Abdollahi and Buchnan (1981 b) shown that aflatoxins were not produced by $A$. parasiticus when the organism cultured medium containing peptone plus mineral salts. However, when the microorganism was transferred to a glucose-containing medium, aflatoxin production occured. They also showed that aflatoxin synthesis could be blocked by cycloheximide or actinomycin D (Abdollahi and Buchnan, $1981 \mathrm{~b}$ ). They concluded that glucose or its metabolites act at the transcriptional level, inducing enzymes involved for aflatoxin synthesis.

The relationship between nitrogen assimilation, metabolism and aflatoxin formation has been investigated in a toxigenic and a non-toxigenic strain of Aspergillus parasiticus. Ammonia from the medium is mainly assimilated via NADP-requiring glutamate dehydrogenase. During growth NAD-requiring glutamate dehydrogenase followed an inverse pattern of activity with respect to NADP glutamate dehydrogenase. Alpha-ketoglutarate, the product of NAD glutamate dehydrogenase, stimulated acetate incorporation into aflatoxins. Glutamine synthetase, ornithine transcarbamylase, both utilizing glutamate as substrate were assayed under different growth conditions. An important regulatory role for glutamine synthetase is suggested. The metabolic route of asparagine utilization was also investigated. Both the known pathways, glutamate oxaloacetate transaminase, and glutamate pyruvate transaminase are operative simultaneously. Aflatoxin production is influenced by chemical compounds, including a) carbon source, and glucose, ribose, xylose, and glycerol were considered excellent substrates for both growth and aflatoxin production by $A$. parasiticus (Davis and Diener, 1968), whereas oleic and fumaric acids enhanced growth, but not aflatoxin production (Davis and Diener, 1968). This is due to the fact that carbohydrates induce aflatoxin synthesis, and the use of a readily metabolizable carbohydrate results in an elevated energy, which in turn induce the aflatoxin biosynthesis pathway (Abdollahi and Buchanan, 1981a; Abdollahi and Buchanan, 1981 b); b) amino acids were found not to induce aflatoxin production, except aspartic acid; (c)nitrogen has been reported to stimulate aflatoxin synthesis, for example, organic nitrogen sources especially casamino acids and $\mathrm{NH}_{4} \mathrm{NO}_{3}$, although $\mathrm{NH}_{4} \mathrm{Cl}$ and $\mathrm{NaNO}_{3}$ resulted in lower aflatoxin production. Proline and asparagine stimulated aflatoxin production than the other nitrogen sources (Payne and Hagler, 1983; Reddy et al., 1971).

Minerals, such as $\mathrm{K}, \mathrm{Fe}, \mathrm{Cu}, \mathrm{Mn}, \mathrm{Mg}, \mathrm{Zn}, \mathrm{Mo}$ and $\mathrm{Ca}$, are essential for fungal growth, are involved as prosthetic groups of enzymes ( $\mathrm{Fe}, \mathrm{Cu}, \mathrm{Zn}$ ), act as enzyme activators ( $\mathrm{Mn}, \mathrm{Zn}, \mathrm{Co}$, $\mathrm{Fe}, \mathrm{Ca}$ ), and are important in secondary metabolite biosynthesis such as manganese, iron and zinc. The function of minerals in secondary metabolites is due to the possibility that they function as metalloenzymes for enzymatic activities (Detroy and Ciegler, 1971) and as catalysts of lipid peroxidation (Maggon et al., 1973). Zn has been shown to play a major role in fumarate synthesis and carbohydrate metabolism because of its effects on the utilization of carbohydrates (Berry, 1975). For example, Zn was reported to affect glycolytic and tricarboxylic acid cycle enzymes, glycolysis by the EMP pathway in A. parasiticus, leading to pyruvate accumulation (Gupta et al., 1976) and phosphogluconate cycle (Grigorov et al., 1979).

Since information about the effects of genetic background of corn hybrids and mycotoxin on corn grain chemical composition is limited, especially for stacked-gene hybrids, the current research was conducted. The objective of this study was to investigate the possible influence of grain chemical composition (protein, oil, fatty acids, sugars and minerals) as affected by genetic backgrounds classes (Non-GMO, RR, and stacked-gene) and toxigenic Aspergillus favus inoculation in corn hybrids under irrigated field conditions in the Mississippi Delta. The current study was a part of a bigger study, previously conducted by Bruns (2014) and Abbas et al. (2016).

\section{Materials and Methods}

\section{Experimental Site and Conditions}

The experiment was conducted at two sites (a Bosket fine sandy loam: fine-loamy, mixed, active, thermic Mollic Hapludalfs, located at the Mississippi State University Delta Branch Research and Extension Center, Stoneville, MS; and a Tunica clay: clayey over loamy, smectitic, nonacid, thermic Vertic Haplaquept at a private property $1.5 \mathrm{~km}$ north of Elizabeth, MS, USA). Corn hybrids, their growth, and field management were reported previously (Bruns, 2014; Abbas et al., 2016). Ten corn hybrids, four stacked-gene (Stgene), four glyphosate-tolerant (RR), and two non-GMO, were used as plant materials. The experiment was planted on April 7, 2011 in conventional tillage plots, furrow irrigated, whereas field management was conducted as described previously (Bruns, 2014). Rows within each plot were inoculated at the $\mathrm{V} 10$ stage of growth with toxigenic Aspergillus flavus K54 (NRRL 58987), isolated from corn kernels in Mississippi, grown on wheat, and applied at a rate of $22.42 \mathrm{~kg} \mathrm{ha}^{-1}$ (Accinelli et al., 2014). The remaining six rows that were naturally infected with disease-producing fungi, including Fusarium and Aspergillus spp., were used as control. The cost, yield, net return per acre, and yield components for the ten hybrids as well as the evaluation of transgenic corn hybrids for mycotoxin control were described previously (Bruns, 2014; Abbas et al., 2016).

\section{Grain Mineral, N, S, and C Analysis}

Mature, dry corn grains were ground to pass through a $1-\mathrm{mm}$ sieve using a Laboratory Mill 3600 (Perten, Springfield, IL, USA), and the ground dried samples were used for analysis. Briefly, a $0.6 \mathrm{~g}$ ground sample was digested in $\mathrm{HNO}_{3}$ with a microwave digestion system, and the mineral content was determined using inductively coupled plasma spectrometry (Thermo Jarrell-Ash 
Model 61E ICP and Thermo Jarrell-Ash Autosampler 300) (Bellaloui et al., 2011, 2014). A 0.25-g sample was combusted, and the percentages of $\mathrm{C}, \mathrm{N}$ and $\mathrm{S}$ were determined using $\mathrm{a}$ $\mathrm{C} / \mathrm{N} / \mathrm{S}$ elemental analyzer (Bellaloui et al., 2011, 2014).

\section{Grain Analysis for Protein, Oil, and Fatty Acids}

Dried corn grains were processed as described above. Ground corn grain samples from each replicate were analyzed for protein, oil, and starch content using a nearinfrared reflectance diode array feed analyzer (Perten, Spring Field, IL). Calibrations were carried out using PertenThermoGalactic Grams PLS IQ (Perten, Spring Field, IL). The reference samples were analyzed based on the AOAC Official Methods for protein, oil, and starch as described previously (Reddy et al., 2010). The analysis was determined based on dry matter (Reddy et al., 2010). Fatty acids were determined using the AOAC Official Method 996.06 using methyl esters analysis by capillary GC. Total amino acids were calculated from the different individual amino acid according to the AOAC Official Method 982.30 E $(a, b, c)$. Reducing sugars were determined colorimetrically as described by DuBois et al. (1956).

\section{Glucose Determination in Grains}

The concentration of glucose in corn grains was determined by an enzymatic reaction using a Glucose (HK) Assay Kit, Product Code GAHK-20 (Sigma-Aldrich Co, St Lovis, MO USA) as described previously (Bellaloui et al., 20014). The concentration of glucose was measured at $340 \mathrm{~nm}$ using the Beckman Coulter DU 800 spectrophotometer. The concentration was expressed as $\mathrm{mg} \mathrm{g}^{-1}$ dry weight.

\section{Boron Determination}

The concentration of $B$ in corn grains was determined using the azomethine-H method (Lohse, 1982; Dordas et al., 2007). Briefly, dry grains were ground to pass through a $1-\mathrm{mm}$ sieve using a Laboratory Mill 3600 (Perten, Springfield, IL, USA) as described above. A 1.0 -g sample was ashed at $500^{\circ} \mathrm{C}$ and extracted with $20 \mathrm{ml}$ of $2 \mathrm{M} \mathrm{HCl}$ at $90^{\circ} \mathrm{C}$ for $10 \mathrm{~min}$. Then, a $2-\mathrm{ml}$ sample of the filtered mixture was added to $4 \mathrm{ml}$ of buffer solution. The buffer solution contained $25 \%$ ammonium acetate, $1.5 \%$ EDTA, and $12.5 \%$ acetic acid. A 4-ml sample of fresh azomethine- $\mathrm{H}$ solution $(0.45 \%$ azomethine- $\mathrm{H}$ and $1 \%$ of ascorbic acid) (John et al., 1975) was then added. The concentration of $B$ was measured by a Beckman Coulter DU 800 spectrophotometer (Beckman Coulter, Inc., Brea, CA, USA) at $420 \mathrm{~nm}$ (Bellaloui et al., 2014).

\section{Iron Determination}

The concentration of $\mathrm{Fe}$ in corn grains was determined as described by Bandemer and Schaible (1944) and Loeppert and Inskeep (1996). The dried grain was ground using a Laboratory Mill 3600 (Perten, Springfield, IL, USA) as described above. The samples were acid digested and extracted, and the resulting re- duced ferrous Fe reacted with 1,10-phenanthroline as described by Bellaloui et al. (2011, 2014). Briefly, a 2-g ground sample was acid digested, and the soluble constituents were dissolved in $2 \mathrm{M}$ of $\mathrm{HCl}$. An aliquot of $4 \mathrm{ml}$, containing 1 to $20 \mu \mathrm{g}$ of iron of the sample solution, was transferred into a $25 \mathrm{ml}$ volumetric flask and diluted to $5 \mathrm{ml}$ using $0.4 \mathrm{M} \mathrm{HCl}$. The quinol solution of $1 \mathrm{ml}$ was added to the $5 \mathrm{ml}$ diluted sample solution and mixed. Then, the phenanthroline solution of $3 \mathrm{ml}$ and $5 \mathrm{ml}$ of the tri-sodium citrate solution $(8 \% \mathrm{w} / \mathrm{v})$ were added. After adding distilled water to $25 \mathrm{ml}$ dilution, the samples were incubated at room temperature for $4 \mathrm{~h}$. Phenanthroline reagent solution of $0.25 \%(\mathrm{w} / \mathrm{v})$ in $25 \%(\mathrm{v} / \mathrm{v})$ ethanol and quinol solution $(1 \%$ $\mathrm{w} / \mathrm{v}$ ) was prepared. The standard curve for Fe was conducted by preparing concentrations, ranging from 0.0 to $4 \mu \mathrm{g} \mathrm{ml}^{-1}$ of $\mathrm{Fe}$ in $0.4 \mathrm{M} \mathrm{HCl}$. The concentration of Fe was performed by the Beckman Coulter DU 800 spectrophotometer at an absorbance of $510 \mathrm{~nm}$.

\section{Phosphorus Determination}

The concentration of $P$ in corn grain was determined by the yellow phosphor-vanado-molybdate complex method according to Cavell (1955). The method was previously described and reported by others Bellaloui et al. (2009, 2014). Briefly, dry corn grains were ground by a Laboratory Mill 3600 (Perten, Springfield, IL, USA) as described above. A ground sample of $2 \mathrm{~g}$ was ashed at $500^{\circ} \mathrm{C}$, and then $10 \mathrm{ml}$ of $6 \mathrm{M} \mathrm{HCl}$ were added. Then, the samples were placed in a water bath at $100^{\circ} \mathrm{C}$ to dryness. Extraction of $P$ was conducted with $2 \mathrm{ml}$ of $36 \% \mathrm{v} / \mathrm{v} \mathrm{HCl}$ under heat and filtration, then $5 \mathrm{ml}$ of $5 \mathrm{M} \mathrm{HCl}$ and $5 \mathrm{ml}$ of ammonium molybdate-ammonium metavanadate reagent were added to 5 $\mathrm{ml}$ of the filtrate. Ammonium molybdate-ammonium metavanadate was prepared by dissolving $25 \mathrm{~g}$ of ammonium molybdate and $1.25 \mathrm{~g}$ of ammonium metavanadate in $500 \mathrm{ml}$ of distilled water. The $\mathrm{P}$ standard curve was performed by preparing a range of $P$ concentrations from 0 to $50 \mu \mathrm{g} \mathrm{ml}^{-1}$ using dihydrogen orthophosphates. The concentration of $P$ was determined at 400 $\mathrm{nm}$ using the Beckman Coulter DU 800 spectrophotometer.

\section{Experimental Design and Statistical Analysis}

The experimental was a randomized complete block design with four replicates. Analysis of variance (ANOVA) was performed using PROC MIXED in SAS 6.1 (Cary, NC, USA). Genotype and soil were modeled as fixed effects. Repetition was considered as a random effect. Residuals of the random effect factor were shown as covariance parameters. Residuals refer to Restricted Maximum Residual Likelihood (REML) values, reflecting the total variance of the random parameters in the model. Means in each hybrid class (Non-GMO, RR, and Stgene) separated by Fisher's protected LSD (0.05). 
Results

ANOVA

The results showed that soil (clay or sandy), genetic background, treatments, and their interactions had significant $(P \leq 0.05)$ effects on seed composition (protein, starch, glucose, stearic, oleic, and linoleic acids), macro-nutrients ( $\mathrm{Ca}, \mathrm{Mg}, \mathrm{C}$, and $\mathrm{N}$ ) (Table $1-4)$. However, $K$ and $P$ were affected by soil and genetic background, but not their interactions (Table 2). Treatments had significant effects on all seed composition constituents and macroand micro-nutrients, except for S (Table 1-4). Soil did not have significant effects on glucose and reducing sugars (Table 1).
Effect of Genetic Backgrounds on Grain Chemical Composition and Mineral Nutrition in Clay Inoculated and Non-Inoculated Soil

Grains of plants grown in clay and inoculated soil showed that oil, starch, glucose, oleic acid were higher in Non-GMO (conventional) and RR than in stacked gene hybrids. However, total amino acids were higher in Non-GMO and stacked gene hybrids. Nutrients, such as $\mathrm{Ca}, \mathrm{K}, \mathrm{Mg}, \mathrm{N}$, were significantly higher in Non-GMO and RR than stacked gene hybrids (Table 5 and 6). However, $P$ was the highest in stacked gene hybrids, and $C$ was higher in stacked gene hybrids and Non-GMO, and $B$ and Zn was higher in RR and stacked gene hybrid than Non-GMO (Table 5 and 6). For grains of plants grown in clay and non-inoc-

Table 1. Analysis of variance ( $F$ values and $P$ values) for the effects of soil, genetic background (Genback: Non-GMO, RR, or stacked gene) of hybrids classes, treatments (Trt: inoculated or non-inoculated with Aspergillus flavus K54), and their interactions on chemical composition compounds (\%) in corn grown in sandy and clay soils under Mississippi delta conditions.

\begin{tabular}{|c|c|c|c|c|c|c|c|c|c|c|c|}
\hline Effect & DF & & Protein & Oil & & Starch & & Glucose & & $\begin{array}{l}\text { Reducing } \\
\text { Sugars }\end{array}$ & \\
\hline & & F-value & P-value & F-value & P-value & F-value & P-value & F-value & P-value & F-value & P-value \\
\hline Soil & 1 & 980 & $<.0001$ & 71.1 & $<.0001$ & 242 & $<.0001$ & 1.3 & 0.255 & 0.2 & 0.655 \\
\hline Soil×Genback & 2 & 10.4 & $<.0001$ & 2.1 & 0.132 & 7.2 & 0.001 & 13.0 & $<.0001$ & 4.1 & 0.019 \\
\hline Trt & 1 & 429 & $<.0001$ & 88.1 & $<.0001$ & 335 & $<.0001$ & 59.6 & $<.0001$ & 152 & $<.0001$ \\
\hline Soil $\times$ Genback $\times$ Trt & 2 & 0.0 & 1.000 & 0.7 & 0.511 & 0.1 & 0.914 & 0.2 & 0.831 & 3.1 & 0.048 \\
\hline Residuals & & 0.138 & & 0.407 & & 0.774 & & 6.124 & & 0.226 & \\
\hline
\end{tabular}

Table 2. Analysis of variance ( $F$ values and $P$ values) for the effects of soil, genetic background (Genback: Non-GMO, RR, or stacked-gene) of hybrids classes, treatments (Trt: inoculated or non-inoculated with Aspergillus flavus K54), and their interactions on macro-nutrients (\%) in corn grown in sandy and clay soils under Mississippi delta conditions.

\begin{tabular}{|c|c|c|c|c|c|c|c|c|c|c|c|c|c|}
\hline & & $\mathrm{Ca}$ & & K & & $\mathrm{Mg}$ & & $\mathbf{P}$ & & C & & $\mathbf{N}$ & \\
\hline Effect & DF & F-value & P-value & F-value & P-value & F-value & P-value & F-value & P-value & F-value & P-value & F-value & P-value \\
\hline Soil & 1 & 82.0 & $<.0001$ & 122 & $<.0001$ & 63.3 & $<.0001$ & 29.1 & $<.0001$ & 123 & $<.0001$ & 443 & $<.0001$ \\
\hline Soil $\times$ Genback & 2 & 59.7 & $<.0001$ & 0.7 & 0.509 & 10.2 & $<.0001$ & 0.6 & 0.556 & 10.2 & $<.0001$ & 11.3 & $<.0001$ \\
\hline Trt & 1 & 179 & $<.0001$ & 37.0 & $<.0001$ & 69.4 & $<.0001$ & 358 & $<.0001$ & 11.5 & 0.001 & 360 & $<.0001$ \\
\hline Soil $\times$ Genback $\times$ Trt & 2 & 51.5 & $<.0001$ & 4.4 & 0.014 & 9.3 & 0.000 & 7.2 & 0.001 & 0.7 & 0.518 & 0.6 & 0.536 \\
\hline Residuals & & 0.0004 & & 0.002 & & 0.0002 & & 0.0003 & & 0.029 & & 0.005 & \\
\hline
\end{tabular}

Table 3. Analysis of variance ( $F$ values and $P$ values) for the effects of soil, genetic background (Genback: Non-GMO, RR, or stacked-gene) of hybrids classes, treatments (Trt: inoculated or non-inoculated with Aspergillus flavus K54), and their interactions on micro-nutrients (\%) in corn grown in sandy and clay soils under Mississippi delta conditions.

\begin{tabular}{|c|c|c|c|c|c|c|c|c|c|c|c|}
\hline Effect & DF & B & & $\mathrm{Cu}$ & & $\mathbf{F e}$ & & Mn & & Zn & \\
\hline & & F-value & P-value & F-value & P-value & F-value & P-value & F-value & P-value & F-value & P-value \\
\hline Soil & 1 & 0.8 & 0.382 & 21.4 & $<.0001$ & 64.5 & $<.0001$ & 88.2 & $<.0001$ & 185 & $<.0001$ \\
\hline Soil ×Genback & 2 & 4.7 & 0.011 & 1.9 & 0.159 & 1.5 & 0.237 & 6.1 & 0.003 & 1.4 & 0.250 \\
\hline Trt & 1 & 156 & $<.0001$ & 17.7 & $<.0001$ & 45.2 & $<.0001$ & 38.4 & $<.0001$ & 192 & $<.0001$ \\
\hline Soil $\times$ Trt & 1 & 0.0 & 0.975 & 30.9 & $<.0001$ & 0.5 & 0.477 & 9.2 & 0.003 & 18.9 & $<.0001$ \\
\hline Soil $\times$ Genback $\times$ Trt & 2 & 0.3 & 0.738 & 0.1 & 0.954 & 0.1 & 0.869 & 4.0 & 0.021 & 0.5 & 0.608 \\
\hline Residuals & & 0.294 & & 0.230 & & 27.605 & & 0.292 & & 4.190 & \\
\hline
\end{tabular}


Table 4. Analysis of variance ( $F$ values and $P$ values) for the effects of soil, genetic background (Genback: Non-GMO, RR, or stacked-gene) of hybrids classes, treatments (Trt: inoculated or non-inoculated with Aspergillus flavus K54), and their interactions on total amino acids (\%) and fatty acids (\% of total oil) in corn grown in sandy and clay soils under Mississippi delta conditions.

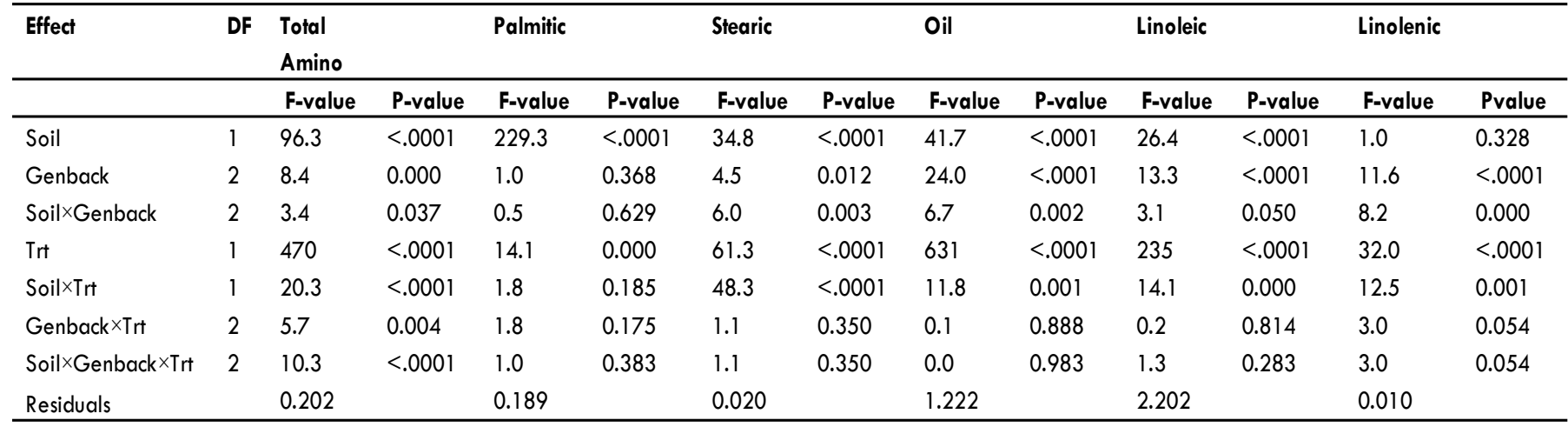

ulated soil, seed protein was higher in RR, and oil, stearic, C, and Cu were higher in Non-GMO and stacked gene hybrids than RR. Glucose, total amino acids, linoleic acid and linolenic acids, K, P, $\mathrm{S}, \mathrm{B}$, and $\mathrm{Zn}$ were higher in RR and stacked gene than Non-GMO hybrids (Table 7 and 8). Oleic acid was higher in Non-GMO than in RR and stacked gene hybrids, but linoleic and linolenic acids were higher in RR and stacked gene than in Non-GMO (Table 7 and 8). Comparing non-inoculated with inoculated conditions, grains grown in inoculated plots had higher protein, starch, total amino acids, oleic acid, Ca, K, and Mg (Table 5-8).

\section{Effect of Genetic Backgrounds on Grain Chemical Composition and Mineral Nutrition in Sandy Inoculated and Non-Inoculated Soil}

In sandy and inoculated soil, grains in Non-GMO and stacked gene hybrids had higher starch, glucose, N, but reducing sugars, total amino acids, $B$, and $C u$ were higher in Non-GMO and RR (Table 9 and 10). Stacked gene hybrids had higher oil, $P$, and $C$ than Non-GMO and RR (Table 9 and 10). In sandy soil and non-inoculated soil, Non-GMO and stacked gene hybrid showed higher starch, glucose, and Mg than RR, but total amino acids

Table 5. Corn grain chemical composition components (\%) as affected by genetic backgrounds (Non-GMO, RR, or stacked-gene) in inoculated clay soil with Aspergillus flavus K54 to produce mycotoxins under Mississippi Delta.

\begin{tabular}{lllllllllllll}
\hline $\begin{array}{l}\text { Hybrid } \\
\text { Classes }\end{array}$ & Protein & Oil & Fiber & Starch & Glucose & $\begin{array}{l}\text { Reducing } \\
\text { sugars }\end{array}$ & $\begin{array}{l}\text { Total amino } \\
\text { acids }\end{array}$ & Palmitic & Stearic & Oleic & Linoleic & Linolenic \\
\hline NON-GMO & 11.6463 & 4.06 & 1.10 & 66.24 & 60.90 & 1.84 & 10.98 & 13.89 & 2.20 & 33.47 & 47.55 & 1.24 \\
RR & 11.7063 & 3.94 & 1.10 & 66.21 & 60.51 & 1.75 & 9.84 & 14.08 & 2.07 & 32.60 & 49.09 & 1.36 \\
Stacked genes & 11.6481 & 3.78 & 1.04 & 65.64 & 57.31 & 1.88 & 10.14 & 14.00 & 2.21 & 31.26 & 49.89 & 1.21 \\
LSD & 0.0406 & 0.22 & 0.05 & 0.25 & 0.56 & 0.13 & 0.15 & 0.09 & 0.03 & 0.25 & 0.31 & 0.03 \\
\hline
\end{tabular}

Table 6. Corn grain macro- and micro-nutrients (\%) as affected by genetic backgrounds (Non-GMO, RR, or stackedgene) in inoculated clay soil with Aspergillus flavus K54 to produce mycotoxins under Mississippi Delta.

\begin{tabular}{lllllllllllll}
\hline Hybrid Classes & $\mathbf{C a}$ & $\mathbf{K}$ & $\mathbf{M g}$ & $\mathbf{P}$ & $\mathbf{C}$ & $\mathbf{N}$ & $\mathbf{S}$ & $\mathbf{B}$ & $\mathbf{C u}$ & $\mathbf{F e}$ & $\mathbf{M n}$ & $\mathbf{Z n}$ \\
\hline Non-GMO & 0.026 & 0.521 & 0.149 & 0.265 & 42.70 & 1.40 & 0.11 & 2.76 & 2.09 & 28.99 & 3.73 & 27.45 \\
RR & 0.017 & 0.536 & 0.142 & 0.262 & 42.44 & 1.45 & 0.12 & 3.43 & 1.98 & 30.27 & 3.78 & 28.57 \\
Stacked genes & 0.011 & 0.431 & 0.130 & 0.276 & 42.60 & 1.36 & 0.11 & 3.10 & 2.14 & 28.58 & 3.81 & 28.23 \\
LSD & 0.001 & 0.011 & 0.004 & 0.004 & 0.065 & 0.023 & 0.002 & 0.19 & 0.14 & 2.01 & 0.14 & 0.70 \\
\hline
\end{tabular}

Table 7. Corn grain chemical composition components (\%) as affected by genetic backgrounds (Non-GMO, RR, or stacked-gene) in non-inoculated clay soil with Aspergillus flavus K54 to produce mycotoxins under Mississippi Delta.

\begin{tabular}{|c|c|c|c|c|c|c|c|c|c|c|c|c|}
\hline $\begin{array}{l}\text { Hybrid } \\
\text { Classes }\end{array}$ & Protein & Oil & Fiber & Starch & Glucose & $\begin{array}{l}\text { Reducing } \\
\text { sugars }\end{array}$ & $\begin{array}{l}\text { Total amino } \\
\text { acids }\end{array}$ & Palmitic & Stearic & Oleic & Linoleic & Linolenic \\
\hline Non-GMO & 10.30 & 5.09 & 1.02 & 63.97 & 60.27 & 3.24 & 8.19 & 14.11 & 2.55 & 28.08 & 51.98 & 1.24 \\
\hline RR & 10.36 & 4.64 & 1.36 & 64.17 & 63.67 & 2.24 & 8.56 & 14.16 & 2.42 & 27.32 & 54.31 & 1.28 \\
\hline Stacked genes & 10.30 & 5.00 & 1.01 & 63.51 & 64.09 & 2.48 & 8.33 & 14.22 & 2.56 & 26.15 & 54.42 & 1.39 \\
\hline LSD & 0.041 & 0.221 & 0.058 & 0.681 & 0.563 & 0.131 & 0.140 & 0.103 & 0.035 & 0.241 & 0.364 & 0.026 \\
\hline
\end{tabular}


Table 8. Corn grain macro- and micro-nutrients (\%) as affected by genetic backgrounds (Non-GMO, RR, or stacked-gene) in non-inoculated clay soil with Aspergillus favus K54 to produce mycotoxins under Mississippi Delta.

\begin{tabular}{|c|c|c|c|c|c|c|c|c|c|c|c|c|}
\hline Hybrid class & $\mathrm{Ca}$ & $\mathbf{K}$ & $\mathbf{M g}$ & $\mathbf{P}$ & C & $\mathbf{N}$ & $\mathbf{s}$ & B & $\mathrm{Cu}$ & $\mathbf{F e}$ & Mn & Zn \\
\hline Non-GMO & 0.006 & 0.369 & 0.100 & 0.321 & 42.78 & 1.71 & 0.117 & 3.97 & 2.87 & 36.03 & 4.57 & 29.98 \\
\hline RR & 0.014 & 0.383 & 0.125 & 0.327 & 42.49 & 1.72 & 0.147 & 4.56 & 2.76 & 37.22 & 3.79 & 32.52 \\
\hline Stacked genes & 0.006 & 0.372 & 0.101 & 0.342 & 42.65 & 1.60 & 0.131 & 4.15 & 2.92 & 34.12 & 3.82 & 31.47 \\
\hline LSD & 0.0004 & 0.011 & 0.003 & 0.004 & 0.1 & 0.681 & 0.002 & 0.191 & 0.144 & 2.007 & 0.132 & 0.713 \\
\hline
\end{tabular}

Table 9. Corn grain chemical composition components (\%) as affected by genetic backgrounds (Non-GMO, RR, or stacked-gene) in inoculated sandy soil with Aspergillus flavus K54 to produce mycotoxins under Mississippi Delta.

\begin{tabular}{lllllllllllll}
\hline $\begin{array}{l}\text { Hybrid } \\
\text { classes }\end{array}$ & Protein & Oil & Fiber & Starch & Glucose & $\begin{array}{l}\text { Reducing } \\
\text { sugars }\end{array}$ & $\begin{array}{l}\text { Total amino } \\
\text { acids }\end{array}$ & Palmitic & Stearic & Oleic & Linoleic & Linolenic \\
\hline Non-GMO & 10.08 & 2.85 & 1.11 & 64.88 & 59.35 & 1.71 & 9.32 & 14.77 & 2.43 & 33.94 & 47.66 & 1.19 \\
RR & 9.43 & 2.99 & 1.02 & 63.81 & 57.28 & 1.64 & 9.36 & 15.19 & 2.51 & 32.45 & 48.84 & 1.16 \\
Stacked genes & 9.48 & 3.22 & 1.05 & 64.17 & 60.42 & 1.58 & 9.06 & 15.01 & 2.45 & 32.61 & 49.00 & 1.23 \\
LSD & 0.140 & 0.127 & 0.047 & 0.260 & 0.784 & 0.122 & 0.681 & 0.143 & 0.051 & 0.366 & 0.436 & 0.026 \\
\hline
\end{tabular}

Table 10. Corn grain macro- and micro-nutrients (\%) as affected by genetic backgrounds (Non-GMO, RR, or stacked-gene) in inoculated sandy soil with Aspergillus flavus K54 to produce mycotoxins under Mississippi Delta.

\begin{tabular}{|c|c|c|c|c|c|c|c|c|c|c|c|c|}
\hline Hybrid classes & $\mathrm{Ca}$ & $\mathbf{K}$ & $\mathbf{M g}$ & $\mathbf{P}$ & $\mathrm{C}$ & $\mathbf{N}$ & 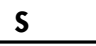 & B & $\mathrm{Cu}$ & $\mathrm{Fe}$ & $M n$ & $Z_{n}$ \\
\hline Non-GMO & 0.010 & 0.343 & 0.107 & 0.243 & 42.19 & 1.20 & 0.118 & 3.19 & 2.24 & 24.16 & 2.52 & 21.66 \\
\hline $\mathrm{RR}$ & 0.010 & 0.360 & 0.110 & 0.256 & 42.22 & 1.18 & 0.738 & 3.08 & 2.16 & 22.50 & 2.71 & 22.36 \\
\hline Stacked genes & 0.010 & 0.312 & 0.111 & 0.287 & 42.28 & 1.20 & 0.112 & 2.79 & 2.03 & 21.95 & 2.75 & 21.84 \\
\hline LSD & 0.000 & 0.015 & 0.003 & 0.004 & 0.032 & 0.018 & 0.443 & 0.109 & 0.116 & 0.487 & 0.146 & 0.339 \\
\hline
\end{tabular}

Table 11. Corn grain chemical composition components (\%) as affected by genetic backgrounds (Non-GMO, RR, or stacked-gene) in non-inoculated sandy soil with Aspergillus flavus K54 to produce mycotoxins under Mississippi Delta.

\begin{tabular}{lllllllllllll}
\hline Hybrid classes & Protein & Oil & Fiber & Starch & Glucose & $\begin{array}{l}\text { Reducing } \\
\text { sugars }\end{array}$ & $\begin{array}{l}\text { Total amino } \\
\text { acids }\end{array}$ & Palmitic & Stearic & Oleic & Linoleic & Linolenic \\
\hline Non-GMO & 8.87 & 3.86 & 1.08 & 65.58 & 62.95 & 2.83 & 8.24 & 15.50 & 2.42 & 29.84 & 51.24 & 1.36 \\
RR & 8.22 & 4.00 & 1.01 & 64.55 & 60.80 & 2.87 & 8.04 & 15.35 & 2.48 & 28.50 & 51.20 & 1.39 \\
Stacked genes & 8.27 & 4.23 & 1.04 & 65.08 & 63.11 & 2.58 & 7.61 & 15.23 & 2.56 & 28.68 & 51.66 & 1.29 \\
LSD & 0.140 & 0.127 & 0.048 & 0.215 & 0.805 & 0.144 & 0.099 & 0.136 & 0.036 & 0.352 & 0.511 & 0.032 \\
\hline
\end{tabular}

Table 12. Corn grain chemical composition components (\%) as affected by genetic backgrounds (Non-GMO, RR, or stacked gene) in non-inoculated sandy soil with Aspergillus flavus K54 to produce mycotoxins under Mississippi Delta.

\begin{tabular}{|c|c|c|c|c|c|c|c|c|c|c|c|c|}
\hline Hybrid classes & $\mathrm{Ca}$ & $\mathbf{K}$ & $\mathrm{Mg}$ & $\mathbf{P}$ & C & $\mathbf{N}$ & $\mathbf{S}$ & B & $\mathrm{Cu}$ & $\mathrm{Fe}$ & $M n$ & $\mathrm{Zn}$ \\
\hline Non-GMO & 0.01 & 0.37 & 0.1125 & 0.3038 & 42.3 & 1.385 & 0.1125 & 4.238 & 2.21 & 30.3375 & 3.1000 & 28.2 \\
\hline RR & 0.01 & 0.39 & 0.0987 & 0.3068 & 42.4 & 1.371 & 0.1163 & 4.179 & 2.01 & 27.0563 & 3.6063 & 28.8 \\
\hline Stacked genes & 0.01 & 0.35 & 0.1029 & 0.3062 & 42.3 & 1.380 & 0.1125 & 4.014 & 1.89 & 27.0000 & 3.7500 & 27.4 \\
\hline LSD & 0.000 & 0.012 & 0.005 & 0.006 & 0.681 & 0.012 & 0.002 & 0.103 & 0.131 & 0.587 & 0.181 & 0.481 \\
\hline
\end{tabular}

and linolenic acids, $\mathrm{K}, \mathrm{Cu}$, and $\mathrm{Zn}$ were higher in Non-GMO and RR (Table 11 and 12). Oil was higher in RR and stacked gene hybrids (Table 11). Comparing non-inoculated with inoculated conditions, grains grown in inoculated plots had greater levels of protein, starch, total amino acids, and oleic acid (Table 9-12), similarly as in clay inoculated soil.

\section{Responses of Grain Chemical Composition and Mineral Nutrition to Inoculation in Genetic Background Hybrid Classes in Clay and Sandy Soils}

The results showed that all nutrients in clay soil were higher in inoculated than non-inoculated plots (Table 13-15). In sandy soil (data not shown), only some nutrients were higher under inoculated conditions. In Non-GMO, oleic acid $133.9 \%$ in Inoc vs. $29.8 \%$ in Non-inoc; total amino acids $19.3 \%$ in Inoc vs. $8.2 \%$ in Non-inoc; S $10.117 \%$ in Inoc vs. $0.112 \%$ in Non-inoc; starch $164.9 \%$ in Inoc vs. $61.6 \%$ in Non-inoc; protein $10.1 \%$ in Inoc vs. $8.9 \%$ in Non-inoc) were higher in inoculated than in non-inoculated soil. Similar responses were observed in RR (oleic acid: $32.4 \%$ in Inoc vs. $28.5 \%$ in Non-inoc; total amino acids: $9.4 \%$ in Inoc vs. $8.0 \%$ in Non-inoc; starch: $63.8 \%$ in Inoc vs. $60.5 \%$ in Non-inoc; S: $0.7 \%$ in Inoc vs. $0.12 \%$ in Non-inoc; protein: $9.4 \%$ in Inoc vs. $8.2 \%$ in Non-inoc. In stacked gene hybrids, similar ob- 
Table 13. Corn grain chemical composition, macro-, and micro-nutrients (\%) as affected by inoculated (Inc) and non-inoculated (Non-inc) clay soil in Non-GMO hybrid class under Mississippi Delta.

\begin{tabular}{|c|c|c|c|c|c|c|c|c|c|}
\hline & & Protein & Oil & Starch & $\begin{array}{l}\text { Oleic } \\
\text { acid }\end{array}$ & $\begin{array}{l}\text { Linolenic } \\
\text { acid }\end{array}$ & Glucose & $\begin{array}{l}\text { Reducing } \\
\text { sugars }\end{array}$ & $\begin{array}{l}\text { Total amino } \\
\text { acids }\end{array}$ \\
\hline & $\ln c$ & 11.65 & 4.06 & 66.24 & 33.47 & 51.98 & 60.27 & 3.24 & 10.98 \\
\hline \multirow[t]{2}{*}{ Non-GMO } & Non-Inc & 10.30 & 5.09 & 63.97 & 28.08 & 47.55 & 57.31 & 1.84 & 8.19 \\
\hline & LSD & 0.052 & 0.252 & 0.217 & 0.156 & 0.169 & 0.541 & 0.169 & 0.131 \\
\hline \multicolumn{10}{|c|}{ Macro- and Micro nutrients } \\
\hline \multirow{4}{*}{ Non-GMO } & & $\mathrm{Ca}$ & $\mathrm{K}$ & $P$ & $N$ & $\mathrm{~S}$ & B & $\mathrm{Fe}$ & \\
\hline & Inc & 0.03 & 0.52 & 0.32 & 1.71 & 0.12 & 3.97 & 36.03 & \\
\hline & Non-Inc & 0.01 & 0.37 & 0.27 & 1.40 & 0.11 & 2.76 & 28.99 & \\
\hline & LSD & 0.001 & 0.008 & 0.004 & 0.026 & 0.003 & 0.285 & 4.359 & \\
\hline
\end{tabular}

Table 14. Corn grain chemical composition, macro-, and micro-nutrients (\%) as affected by inoculated (Inc) and non-inoculated (Non-inc) clay soil in glyphosate-resistant hybrid class (RR) under Mississippi Delta.

\begin{tabular}{|c|c|c|c|c|c|c|c|c|c|}
\hline & & Protein & Oil & Starch & Oleic acid & $\begin{array}{l}\text { Linolenic } \\
\text { acid }\end{array}$ & Glucose & $\begin{array}{l}\text { Reducin } \\
\text { g sugars }\end{array}$ & $\begin{array}{l}\text { Total amino } \\
\text { acids }\end{array}$ \\
\hline & Inc & 11.71 & 4.64 & 66.21 & 32.60 & 54.31 & 63.67 & 2.24 & 9.84 \\
\hline \multirow[t]{2}{*}{$\mathbf{R} \mathbf{R}$} & Non-Inc & 10.36 & 3.94 & 64.17 & 27.32 & 49.09 & 60.51 & 1.75 & 8.56 \\
\hline & LSD & 0.028 & 0.194 & 0.297 & 0.233 & 0.407 & 0.385 & 0.084 & 0.169 \\
\hline \multicolumn{10}{|c|}{ Macro- and Micro nutrients } \\
\hline \multirow{4}{*}{$\mathbf{R} \mathbf{R}$} & & $\mathrm{Ca}$ & K & $P$ & $\mathrm{~N}$ & $\mathrm{~S}$ & B & $\mathrm{Fe}$ & \\
\hline & $\operatorname{lnc}$ & 0.02 & 0.54 & 0.33 & 1.72 & 0.15 & 4.56 & 37.22 & \\
\hline & Non-Inc & 0.01 & 0.38 & 0.26 & 1.45 & 0.12 & 3.43 & 30.27 & \\
\hline & LSD & 0.001 & 0.013 & 0.005 & 0.029 & 0.002 & 0.174 & 0.933 & \\
\hline
\end{tabular}

Table 15. Corn grain chemical composition, macro-, and micro-nutrients (\%) as affected by inoculated (Inc) and non-inoculated (Noninc) clay soil in stacked-gene hybrid under Mississippi Delta.

\begin{tabular}{|c|c|c|c|c|c|c|c|c|c|}
\hline & & Protein & Oil & Starch & Oleic acid & Linolenic acid & Glucose & Reducing sugars & Total amino acids \\
\hline & $\operatorname{lnc}$ & 11.65 & 5.00 & 65.64 & 31.26 & 54.42 & 64.09 & 10.14 & 2.48 \\
\hline \multirow[t]{2}{*}{ Stacked genes } & Non-Inc & 10.30 & 3.78 & 63.51 & 26.15 & 49.89 & 60.90 & 8.33 & 1.88 \\
\hline & LSD & 0.041 & 0.192 & 0.135 & 0.228 & 0.204 & 0.611 & 0.074 & 0.135 \\
\hline \multicolumn{10}{|c|}{ Macro- and Micro nutrients } \\
\hline \multirow{4}{*}{ Stacked genes } & & $\mathrm{Ca}$ & K & $P$ & $N$ & $\mathrm{~S}$ & B & $\mathrm{Fe}$ & \\
\hline & $\operatorname{lnc}$ & 0.02 & 0.54 & 0.33 & 1.72 & 0.15 & 4.56 & 37.22 & \\
\hline & Non-lnc & 0.01 & 0.38 & 0.26 & 1.45 & 0.12 & 3.43 & 30.27 & \\
\hline & LSD & 0.001 & 0.013 & 0.005 & 0.029 & 0.002 & 0.174 & 0.933 & \\
\hline
\end{tabular}

servations were recorded for protein, oleic acid, Cu, starch, and total amino acids (data not shown). Although protein was higher in Inoc treatment in sandy soil than in Non-GMO and stacked gene, oil was higher in Non-inoc treatment than in Non-GMO and stacked gene. For example, in Non-GMO oil was $3.9 \%$ in Non-inoc vs. $2.8 \%$ in Inoc, and similar pattern was observed in stacked gene hybrid (data not shown).

\section{Discussion}

The effects of soil, genetic background, and inoculation treatment on seed nutrients show the significant contribution of abiotic factors, such as soil, and biotic factors, such as genotype and diseases, mycotoxins, and nutrients. It has been reported that mycotoxin production is affected by the soil type, since corn planted in clay soil has higher levels of mycotoxin than this grown in sandy soil. The level of nutrients in grains grown in clay soil were higher than that grown in sandy soil. However, this observation cannot be due necessary to the inoculation treatment only. For example, heat and drought stress can induce both inoculated and non-inoculated plots, reducing the uptake of nutrients by the crop and limiting the movement of nutrients from source (leaves) to sink (grains). It was reported that mycotoxin production is influenced by environmental conditions such as heat, drought, insect infestation level, and various plant diseases (Diener et al., 1987; Payne, 1992; Abbas et al., 2002; Bruns and Abbas, 2005; De la Campa et al., 2005; Bruns and Abbas, 2006; Abbas et al., 2007). In the Mississippi delta, drought and heat are major environmental factors that affect corn growth, limiting factor nutrient uptake and accumulation. 
Although the current experiment was irrigated, the possibility that the crop suffered drought cannot be excluded. Different response of nutrients in hybrid classes grown in sandy soil compared with those grown in clay soil could be due to the fact that sandy soil creates additional stress due to warmer and drier season, especially during the kernel-filling stage and may contribute to higher aflatoxin contamination in sandy soils. In addition, the field water holding capacity of sandy soils is lower than that of clay soils, exposing the grain to higher drought and heat stress. It was recently found that the level of aflatoxin in sandy loam soil was higher compared with that in clay soil, possibly leading to lower yield of hybrids grown in sandy soil compared with that grown in clay soil even when irrigation takes place (Abbas et al., 2007; Bruns, 2014; Kebede et al., 2012).Under clay and sandy soil conditions with inoculation, the levels of protein, oleic acid, total amino acids, and starch, and some nutrients such as $\mathrm{Ca}, \mathrm{K}$, and $\mathrm{Mg}$ responded positively, indicating that these compounds are stress indicators, supporting the observation that a stress condition maybe occurred for the corn grown under inoculated conditions. Meanwhile, the higher protein and oleic acid resulted in lower oil and linoleic acid in some cases, reflecting the inverse relationship between protein and oil (Kebede et al., 2012 ) and oleic and linoleic and linolenic acids. Previous studies reported that aflatoxin production is stimulated by high carbohydrate, low protein, (Thalmann, 1990; Ellis et al., 1991) and metal ion, such $\mathrm{Cd}^{2+}, \mathrm{Mg}^{2+}, \mathrm{Ca}^{2+}$, and $\mathrm{Zn}^{2+}$ (Failla et al., 1986; Stossel, 1986; Ellis et al., 1991; Viquez et al., 1994) levels. Zn is required for aflatoxin biosynthesis (Failla et al., 1986; Stossel, 1986) and $\mathrm{Ca}^{2+}$ content may reduce aflatoxin contamination (Mixon et al., 1984). Abdollahi and Buchnan (1981 a) found that ribose, xylose, glucose, fructose, sorbose, mannose, galactose, maltose, sucrose, raffinose, and glycerol induced aflatoxin production, but aflatoxin biosynthesis was not induced by lactose, lactic acid, sodium pyruvate, oleic acid, and citric acid. The involvement of these carbohydrates may be due to specific carbon source metabolites, inducing enzymes involved for aflatoxin synthesis and aflatoxin production. It was reported that glucose, ribose, xylose, and glycerol were considered excellent substrates for growth and aflatoxin production by A. parasiticus (Davis and Diener (1968), because they elevate energy level that is used for aflatoxin biosynthesis pathway (Abdollahi and Buchanan, $1981 a$; Abdollahi and Buchanan, 1981b). Minerals, such as K, $\mathrm{Fe}, \mathrm{Cu}, \mathrm{Mn}, \mathrm{Mg}, \mathrm{Zn}, \mathrm{Mo}$, and Ca, are essential for fungal growth, are involved as prosthetic groups of enzymes ( $\mathrm{Fe}, \mathrm{Cu}$, and $\mathrm{Zn}$ ), act as enzyme activators ( $\mathrm{Mn}, \mathrm{Zn}, \mathrm{Co}, \mathrm{Fe}$, and $\mathrm{Ca}$ ), and are important in secondary metabolite biosynthesis such as $\mathrm{Mn}, \mathrm{Fe}$, and $\mathrm{Zn}$. In our study, protein, oleic acids, carbohydrates (glucose, reducing sugars, and starch), and total amino acids were higher under inoculated conditions in clay and sandy soils, indicating the stress indicators role of these compounds. The results showed that the level of these nutrients was higher under inoculated conditions. However, further research is needed in nutrient deficient soils with inoculation.

\section{Conclusions}

The current study showed that no nutritional advantage was observed using the stacked gene hybrids over glyphosate-resistant or non-GMO hybrids, and this could be due to the soils used had adequate nutrient concentrations. However, these results are not conclusive as the current experiment was irrigated and the level of inoculation may not be severe enough to impact the yield and nutrient uptake and nutrient mobility to the grains. Therefore, conducting a multi-year experiment with a bigger number of hybrids under different conditions of irrigated and non-irrigated and with a severe level of infection would contribute to further knowledge. Higher levels of protein, carbohydrates, and total amino acids, and some minerals were noticed under inoculated condition, but further investigation is needed. The higher levels of these compounds under inoculated conditions could be due to a possible osmotic adjustment role and osmoprotectants (Zhu, 2002; Serraj and Sinclair, 2002; Farooq et al., 2009; Marschner, 2012) under inoculation stress. Research on the effects of mycotoxin on the performance of Non-GMO, $R R$, and especially stacked-gene hybrids is limited and needs further investigation (Abbas et al., 2016), especially on the nutritional aspect.

\section{Acknowledgements}

We would like to thank Sandra Mosley for lab analyses and technical assistance. This study was partially supported by the U.S. Department of Agriculture, Agricultural Research Service Project 6402-21 220-012-00D. Mention of trade names or commercial products in this publication is solely for the purpose of providing specific information and does not imply recommendation or endorsement by the U.S. Department of Agriculture.

\section{References}

Accinelli C, HK Abbas, A Vicari, and WT Shier (2014) Aflatoxin contamination of corn under different agro-environmental conditions and biocontrol applications. Crop Prot. 63: 9-14. http://dx.doi. org/10.1016/i.cropro.2014.04.021

AOAC Official Method 982.30E abc (2006) Amino acids. AOAC International.

AOAC Official Method 996.06 (1997) Fat (total saturated and unsaturated) in foods. AOAC International.

Abbas HK (2005) Aflatoxin and food safety. CRC Press Boca Raton. http://dx.doi.org/10.1201/9781420028171.

Abbas HK, JR Wilkinson, RM Zablotowicz, C Accinelli, CA Abel, HA Bruns, and MA Weaver (2009) Ecology of Aspergillus flavus, regulation of aflatoxin production and management strategies to reduce aflatoxin contamination of corn. Toxin Reviews 2-3:142-152. http:// dx.doi.org/10.1080/15569540903081590.

Abbas HK, MA Weaver, WB Horn, I Carbone, JT Monacell, and WT Shier (2011) Selection of Aspergillus favus isolates for biological control of aflatoxin in corn. Toxin Reviews 30:59-70.

Abbas HK, N Bellaloui, and HA Bruns (2016) Investigating transgenic corn hybrids as a method for mycotoxin control. Food Nutr. Sci. 7:4454. http://dx.doi.org/10.4236/fns.2016.71006.

Abbas HK, RM Zablotowicz, MA Weaver, WT Shier, HA Bruns, and N 
Bellaloui, et al (2013) Implications of Bt traits on mycotoxin contamination in maize: overview and recent experimental results in southern United States. Journal of Agriculture and Food Chemistry 61:11759-11770. doi:10.1021/if400754g.

Abbas HK, RM Zablotowicz, WT Shier, BJ Johnson, NA Phillips, MAWeaver, CA Abel, and HA Bruns (2015) Aflatoxin and fumonisin in corn (Zea mays) infected by common smut Ustilago maydis. Plant Disease 99:1 236-1 240. http://dx.doi.org/10.1094/PDIS-03-14-0234-RE. Abbas HK, WP Williams, GL Windham, JC Pringle Jr, W Xie, and WT Shier (2002) Aflatoxin and fumonisin contamination of commercial corn (Zea mays) hybrids in Mississippi. J. Agric. Food Chem. 50:5246-5254. http://dx.doi.org/10.1021/jf020266k.

Abbas HK, WT Shier, and RD Cartwright (2007) Effect of temperature, rain fall, and planting date on aflatoxin and fumonisin contamination in commercial $\mathrm{B} t$ and non-Bt corn hybrids in Arkansas. Phytoprotection 88:41-50. http://dx.doi.org/10.7202/018054ar.

Abdollahi A, and RL Buchanan (1981a) Regulation of aflatoxin biosynthesis: induction of aflatoxin production by various carbohydrates. J. Food Sci. 46:633-635. doi:10.1111/j.1365-2621.1981. tb04928.x.

Abdollahi A, and RL Buchnan (1981b) Regulation of aflatoxin biosynthesis: characterization of glucose as an apparent inducer of aflatoxin production. J. Food Sci. 46:143-146. doi: 10.1111 /j.1365-2621.1981.tb14549.x.

Bandemer SL, and PJ Schaible (1944) Determination of iron. A study of the o-Phenanthroline method. Industrial and Engineering Chemistry, Analytical Edition 16:317-319. http://dx.doi.org/10.1021/ i560129a013.

Bellaloui N, A Mengistu, ER Walker, and LD Young (2014) Soybean seed composition as affected by seeding rates and row spacing. Crop Sci. 54:1782-1795.

Bellaloui N, JR Smith, AM Gillen, and JD Ray (2011) Effects of maturity, genotypic background, and temperature on seed mineral composition in near-isogenic soybean lines in the early soybean production system. Crop Sci. 51:1161-1171.

Bellaloui N, JR Smith, JD Ray, and AM Gillen (2009) Effect of maturity on seed composition in the early soybean production system as measured on near-isogenic soybean lines. Crop Sci. 49:608-620.

Berry DR (1975) The environmental control of the physiology of filamentous fungi. In: The Filamentous Fungi, volume 1, Industrial Mycology. JE Smith and DR Berry (Eds). Edward Arnold Press London and Halsted Press New York, pp. 16-32.

Bruns HA (2014) Stacked-gene hybrids were not found to be superior to glyphosate resistant or non-GMO corn hybrids. Crop Management.

Bruns HA, and HK Abbas (2005) Responses of short-season corn hybrids to a humid sub-tropical environment. Agron. J. 97:446-451. http://dx.doi.org/10.2134/agronj2005.0446.

Bruns HA, and HK Abbas (2006) Planting date effects on $B t$ and non- $B t$ corn in the Mid South USA. Agron. J. 98:100-106. http://dx.doi. org/10.2134/agronj2005.0143.

CAST (Council for Agriculture Science and Technology) (2003) Mycotoxins risks in plant, animal, and human systems. Task Force Report 139 CAST Ames.

Catangui MA, and RK Berg (2006) Western bean cutworm, Striacosta albicosta (Smith) (Lepidoptera: Noctuidae), as a potential pest of transgenic cry $1 \mathrm{Ab}$ Bacillus thuringiensis corn hybrids in South Dakota. Environ. Entomol. 35:1439-1452. http://dx.doi.org/10.1093/ ee/35.5.1439.

Cavell AJ (1955) The colorimetric determination of phosphorus in plant materials. J. Sci. Food Agric. 6:479-480. http://dx.doi. org/10.1002/isfa.2740060814.
Cook KA, ST Ratcliffe, ME Gray, and KL Steffey (2016) European corn borer insect fact sheet. http://ipm.illinois.edu/fieldcrops/insects/european_corn_borer.pdf (accessed August 4, 2016).

Davis ND, and UL Diener (1968) Growth and aflatoxin production by Aspergillus parasiticus from various carbon sources. Appl. Microbiol. 16:158-9.

De la Campa R, DC Hooker, JD Miller, AW Schaafsma, and BG Hammond (2005) Modeling effects of environment, insect damage, and $\mathrm{B}+$ genotypes on fumonisin accumulation in maize in Argentina and the Philippines. Mycopathologia 159:539-552. http://dx.doi. org/10.1007/s1 1046-005-2150-3.

Detroy RW, and A Ciegler (1971) Aflatoxin biosynthesis in Aspergilus parasiticus: effect of methionine analogs. Can. J. Microbiol. 17:569574.

Diener UL, RJ Cole, TH Sanders, GA Payne, LS Lee, and MA Klich (1987) Epidemiology of aflatoxin formation by Aspergillus favus. Annu. Rev. Phytopathol. 25:249-270. http://dx.doi.org/10.1146/ annurev.py.25.090187.001341.

Dordas C, GE Apostolides, and O Goundra (2007) Boron application affects seed yield and seed quality of sugar beets. J. Agric. Sci. 145:377-384. http://dx.doi.org/10.1017/ S0021859607006879.

DuBois M, KA Gilles, JK Hamilton, PA Rebers, and F Smith (1956) Colorimetric method for determination of sugars and related substances. Analytical Chemistry 28:350-356.

Dutton MF (1988) Enzymes and aflatoxin biosynthesis. Microbiol. Rev. 52:274-295.

Ellis WO, JP Smith, BK Simpson, and JH Oldham Aflatoxins in Food: Occurrence, Biosynthesis, Effects on Organisms, Detection, and Methods of Control. Crit. Rev .Food Sci. Nutri. 30:403-439.

Failla LJ, D Lynn, and WG Niehaus Jr (1986) Correlation of Zn2+ content with ailatoxin content of corn. Appl. Environ. Microbiol. 5:3-74.

Farooq M, A Wahid, N Kobayashi, D Fujita, and SMA Basra (2009) Plant drought stress: effects, mechanisms and management. Agronomy for Sustainable Development, Springer Verlag/EDPSciences/ INRA, 29,185-212. <hal-00886451>. https://hal.archives-ouvertes.fr/hal-00886451/document Verified on September8, 2016

Gupta SK (1976) Biochemical studies on Aspergillus parasiticus. Ph.D. thesis, University of Poona Pune India.

John MK, HH Chuah, and JH Neufeld (1975) Application of improved azomethine- $\mathrm{H}$ method to the determination of boron in soils and plants. Anal. Lett. 8:559-568. http://dx.doi. org/10.1080/00032717508058240.

Kebede H, HK Abbas, DK Fisher, and N Bellaloui (2012) Relationship between aflatoxin contamination and physiological responses of corn plants under drought and heat stress. Toxins 4:1385-1403. http://dx.doi.org/10.3390/toxins4 111385.

King ED, $A B$ Bassi, DC Ross, and B Druebbisch (2011) An industry perspective on the use of atoxigenic strains of Aspergillus flavus as biological control agents and the significance of cyclopiazonic acid. Toxin Reviews 30:33-41. http://dx.doi.org/10.3109/15569543.2 011.588818.

Llewellyn GC, WV Dashek, TD Kimbrough, CE O'Rear, and LB Weekley (1988) Aflatoxin $B 1$ affects feed consumption in male rats through an action on the central nervous system. International Biodeterioration \& Biodegradation 24:417-425.

Loeppert RL, and WP Inskeep (1996) Colorimetric determination of ferrous iron and ferric iron by the 1,10-phenanthroline method. In: Methods of Soil Analysis, JM Bigham (Ed.), Part 3, Chemical Methods, SSSA, Madison WI pp. 659-661.

Lohse G (1982) Microanalytical azomethine-H method for boron determination in plant tissue. Commun. Soil Sci. Plant Anal. 13:127-134. 
http://dx.doi.org/10.1080/00103628209367251.

Marschner P (2012) Marschner's mineral nutrition of higher plants. 3rd Editon. San Diego CA Academic Press.

Maggon KK, S Gopal, and TA Venkitasubranian (1973) Effect of trace metals on aflatoxin production by Aspergillus flavus. Biochem. Physiol. Pflanz. 164:523-530.

Miller CD, JL Richard and GD Osweiler (2011) Cyclopiazonic acid toxicosis in young turkeys: clinical, physiological, and serological observations. Toxin Reviews 30:42-46.

Mixon AC, DK Bell, and DM Wilson (1984) Effect of chemical and biological agents on the incidence of Aspergillus flaws and aflatoxin contamination of peanut seed. Phytopathology 74:1 440-1 444.

Munkvold GP, RL Hellmich, and LG Rice (1999) Comparison of fumonisin concentrations in kernels of transgenic $B t$ maize hybrids and nontransgenic hybrids. Plant Dis. 83:130-138. http://dx.doi. org/10.1094/PDIS.1999.83.2.130.

National Toxicology Program (NTP). (2001) Toxicology and Carcinogenesis Studies of Fumonisin B1 in F344/N Rats and B6C3F1 Mice (Feed Studies). Department of Health \& Human Services, Public Health Service, NTP, Central Data Management, Research Triangle Park.

Ostry V, J Ovesna, J Skarkova, V Pouchova, and J Ruprich (2010) A review on comparative data concerning fusarium mycotoxins in $\mathrm{Bt}$ maize and non- $\mathrm{Bt}$ isogenic maize. Mycotoxin Res. 26:141-145. http://dx.doi.org/10.1007/s12550-010-0056-5.

Payne GA (1992) Aflatoxin in maize. Crit. Rev. Plant Sci. 10:423-440. http://dx.doi.org/10.1080/07352689209382320.

Payne GA, and WM Hagler Jr (1983) Effect of specific amino acids on growth and aflatoxin production by Aspergillus parasiticus and Aspergillus flavus in defined media. Appl. Environ. Microbiol. 46:805-12.

Reddy KN, N Bellaloui, and RM Zablotowicz (2010) Glyphosate effect on shikimate, nitrate reductase activity, yield, and seed composition in corn. J. Agric. Food Chem. 58:3646-50. doi: 10.1021/ jf904121y.

Reddy TV, L Wiswanathan, and TA Venkitasubramanian (1971) High aflatoxin production on a chemically defined medium. Appl. Microbiol. 22:393-396.

Robens J, and K Cardwell (2003) The costs of mycotoxin management to the USA: management of aflatoxins in the United States. Journal of Toxicology: Toxin Reviews 22:139-152. http://dx.doi. org/10.1081/TXR-120024089.

SAS. (Copyright 2002-2010) Statistical Analysis System, Cary NC USA; Windows Version 6.1.7601.

Serraj R, and TR Sinclair (2002) Osmolyte accumulation: can it really help increase crop yield under drought conditions? Plant, Cell \& Envir. 25:333-341.

Sheridan KJ, KD Stephen, and S Doyle (2015) Endogenous cross-talk of fungal metabolites. Front. Microbiol. Published on 05 January. doi: $10.3389 /$ fmicb. 2014.00732 .

Stossel P (1986) Aflatoxin contamination in soybeans: role of proteinase inhibitors, zinc availability, and seed coat integrity. Appl. Environ. Microbiol. 52:36-72.

Thalmann A (1990) Mycotoxines in Cereals. Angewandte Botanik 64:167-173.

Viquez OM, ME Castell-Perez, RA Shelby, and G Brown (1994) Aflatoxin contamination in corn samples due to environmental conditions, aflatoxin-producing strains, and nutrients in grain grown in Costa Rica. J. Agric. Food Chem. 42:2551-2555.

Wiatrak PJ, DL Wright, JJ Marois, and D Wilson (2005) Influence of planting date on aflatoxin accumulation in $\mathrm{Bt}$, non- $\mathrm{Bt}$, and tropical non-Bt hybrids. Agron. J. 97:440-445. http://dx.doi.org/10.2134/ agronj2005.0440

Williams WP, GL Windham, MD Krakowsky, BT Scully, and X Ni (2010) Aflatoxin accumulation in $\mathrm{B} t$ and non-Bt maize test crosses. J. Crop Improv. 24: 392-399. http://dx.doi.org/10.1080/15427528.20 10.505111

Wiseman DW, and RL Buchanan (1987) Determination of glucose level needed to induce aflatoxin production in Aspergillus Parasiticus. Can. J. Microbiol. 33:828-830.

Zhu JK (2002) Salt and drought stress signal transduction in plants, Annu. Rev.Plant Biol. 53:247-273. 